\title{
The Experiences, Opinions and Suggestions of Special Education Teachers Regarding Leisure Time Activities Chosen by Students with Intellectual Disability
}

\author{
Müzeyyen ELDENIZ ÇETIN
}

Special Education, Bolu Abant İzet Baysal University, Bolu, Turkey

ORCID: 0000-0001-9231-7344

\section{Evgin CAY*}

Sakarya SSehit Ali Borinli Special Education Profession School, Sakarya, Turkey ORCID: 0000-0002-1199-3939

\begin{tabular}{|c|c|}
\hline Article history & dentify the \\
\hline $\begin{array}{l}\text { Received: } \\
27.09 .2019\end{array}$ & $\begin{array}{l}\text { suggestions regarding the leisure time activities chosen by intellectually } \\
\text { disabled students. Case study method, one of the qualitative research }\end{array}$ \\
\hline $\begin{array}{l}\text { Received in revised form: } \\
11.12 .2019\end{array}$ & $\begin{array}{l}\text { methods, was used in the study, and the participants were selected } \\
\text { through criterion sampling. A total of } 25 \text { teachers- } 18 \text { females and } 7 \\
\text { males- took part in the study. Data was collected through open-ended }\end{array}$ \\
\hline $\begin{array}{l}\text { Accepted: } \\
15.12 .2019\end{array}$ & $\begin{array}{l}\text { questions and teacher diaries, and then it was analyzed descriptively. The } \\
\text { findings of the study revealed that the teachers did not have any }\end{array}$ \\
\hline Key w & significant problems while teaching leisure time activities and their rules \\
\hline $\begin{array}{l}\text { Intellectual disability, } \\
\text { individual with intellectual } \\
\text { disability, leisure time activity. }\end{array}$ & $\begin{array}{l}\text { to students with intellectual disability, and the students enjoyed working } \\
\text { both individually and as a group during those activities. The findings also } \\
\text { indicated that some students wanted to start another activity without } \\
\text { finishing the current one. In addition, the teachers stated that more } \\
\text { educational activities were necessary, and they expected the government } \\
\text { to provide the schools with such educational games and tools. It was also } \\
\text { found out that the teachers used class hours to teach the leisure time } \\
\text { activities chosen by the students, but they needed more time. Finally, } \\
\text { they stated that they did not experience any trouble with the school } \\
\text { administration with respect to those leisure time activities. }\end{array}$ \\
\hline
\end{tabular}

\section{Introduction}

Individuals make a number of major and minor choices throughout their lives (Cote Sparks \& Cote, 2012). Selecting a spouse, occupation, clothing, food, beverage, vehicle, toy, schools etc. can be some examples of such choices. From this perspective, it can be concluded that making choices is a big part of one's life (Eldeniz Çetin, 2013). As for individuals with special needs, it is even more important.

Being able to make their own decisions and choices increases the life quality of intellectually disabled individuals. Making choices and having the opportunity to make choices are given significant importance in the literature as these will encourage individuals to take responsibility in their lives, help them harmonize with the rest of the society and enable them to live 
independently (Stafford, 2005). Making choices, one sub-category of responsibility assumption (Wood, Karvonen, Test, Browder \& Algozzine, 2004), has a bigger role in a person's life compared to the other sub-categories (making decisions, problem solving etc.) (Wehmeyer, 2003). This is because that particular skill is more essential for individuals with developmental disabilities (intellectual disability, autism spectrum disorder etc.) since it enables them to achieve and maintain a higher life quality (Spevack, Martin, Hiebert, Yu \& Martin, 2004).

Although making choices is a sign of one's having control over life, our choices can affect our lives both negatively and positively. That's why, this skill should be taught to individuals with intellectual disabilities in order to let them have positive outcomes in their lives (Ülke Kürkçüoğlu, 2007). Shevin and Klein (2004) define choice-making skill as one's ability to specify his/her preference among various options. Considering its role in the lives of intellectually disabled individuals, research on this subject is fundamental to lead them to more effective choices (Shogren, Faggelle-Luby, Bae, \& Wehmeyer, 2004). Some examples of related studies are available in the literature (Carter, 2001; Cole \& Levinson, 2002; Newman, Needelman, Reinecke \& Robek, 2002; Peterson, Caniglia \& Royster, 2001; Ülke-Kürkçüoğlu, 2007; Watanabe \& Sturmey, 2003). There is research suggesting that choice-making skill can benefit individuals with autism spectrum disorder while they are stating their preferences and making decisions. However, it is highly possible that people with intellectual disability, emotional disturbance and multiple disabilities will also benefit from it (Shogren et al., 2004).

The research indicates that teaching choice-making skills to individuals with disabilities is of great importance. According to Cote Sparks and Cote (2012), teaching this skill to individuals with special needs has a big role in improving their responsibility and awareness in life. In addition, it is a milestone in one's becoming more independent (Duke, 2008). Teaching such skills to individuals with disabilities will help them to transfer their social, interactive and cognitive skills to various settings. Furthermore, it is known that making choices in house environment can further develop those individuals' choice-making, self-monitoring and social competence skills (McCormick, Julivette \& Ridgley, 2003) Together with that, it will enable them to interact and socialize with their peers better (Stafford, 2005). It will help them to behave in a more restrained and conscious manner, and thus, be accepted by their community, as well. Its positive impacts can also be observed in the behaviors of individuals with intellectual disability in educational settings (Jolivette, 1999). All these achievements are in a way related to other opportunities to emerge for such individuals.

Letting individuals with disabilities demonstrate their preferences reduces their dependence on others (Ülke-Kürkçüoğlu, 2007). Kearney and McKnight (1997) define choice making opportunity as allowing someone to indicate his/her preference among two or more options (e.g.: car, activity, food or beverage). As for activities, giving individuals with disability the opportunity to choose an activity will both decrease their inappropriate behaviors and improve their performance during that activity. In addition, this will enable teachers to have better interactions and communication with them (Jolivette, 1999; Ülke-Kürkçüoğlu, 2007).

Choice-making opportunities may be given to individuals during teaching activities or revision tasks in educational settings. Especially young children should be allowed to choose among various practices, activities and games (Ülke-Kürkçüoğlu, 2007). Teachers should be responsible for the selection of the choices to be given to the students with disability during the day. This skill can be integrated into classroom activities without making any changes or adaptations in the activities themselves (Eldeniz Çetin, 2013). For instance, students can be allowed to choose the place they would like to sit, the in-class activities they want to complete 
and the daily classroom routines they want to follow (Cote et al., 2012). Those students can also be given the opportunity to choose leisure time activities in educational settings.

Leisure time activities are generally integrated into programs followed in preschools and special education institutions. They may include doing art-related activities, playing house, doing nature or science-related activities, reading books, playing with puppets, listening to or producing music, playing with educational toys, spending time at interest corners, kneading dough, doing paper-cutting activities, and painting or crafting unused materials. Classroom teachers can organize these activities according to the levels, characteristics, interests and needs of their own students. While doing such activities individually or as a group, students can learn to cooperate with each other and enjoy the experience (Çay, 2017; MEGEP, 2007). Also, students can be guided according to their interests and abilities during leisure time activities. The word 'leisure' in this context does not mean a teacher's leaving students unattended and letting them spend time aimlessly though (Hanley, Cammilleri, Tiger, \& Ingvarsson, 2007; Murphy, McSweeney, Smith, \& McComas, 2003).

Within the classroom context, the teacher can ensure that students are active during these activities. S/he can plan different things like crafting with unused or recyclable materials. Being involved in such activities will enable children to be more active and sociable. In addition, thanks to leisure time activities done as a group, students will harmonize with their peers and take more responsibility. Besides these, these activities can reveal their abilities rather than emphasizing their disabilities; therefore, leisure time activities are significant for individuals with disabilities (Sucuoğlu, 2009). Göçer (2004) and Farry (2008) both state that leisure time activities are beneficial for individuals with intellectual disability since they ensure permanent learning, develop communication skills, help students generalize acquired skills, ease learning process through group work, improve students' integration into the society and foster their societal existence. The findings of the field research (Bult, Verschuren, Jongmans, Lindeman, \& Ketelaar, 2011; Law, King, King, Kertoy, Hurley, Rosenbaum, \& Hanna, 2006; Majnemer, Shevell, Law, Birnbaum, Chilingaryan, Rosenbaum \& Poulin, 2008; Preskitt, Goldfarb, Mulvihill, Colburn, \& Davis, 2013) support the above-mentioned views.

The international literature involves studies about the effects of having choice-making opportunity on individuals with intellectual disability (Dibley \& Lim, 1999; Dunlap et al., 1994; Foster-Johnson et al., 1994; Frischmeyer \& Millard, 1996; Harding et al., 2002; Jolivette, 1999; Peck, Wacker, Berg, Cooper, Brown, Richman \& McComas; Romaniuk, Miltenberger, Conyers, Jenner, Jurgens \& Ringernberg, 2002; Vaughn \& Horner, 1997) and teaching them those skills (Barry \& Burlew, 2004; Clark, 2006; Duke, 2008; Dutt, 2010; Hoch, 2006). However, the national (Turkish) literature appears to be rather limited in this regard (Eldeniz Çetin, 2013; Ülke Kürkçüoğlu, 2007).

Some studies conducted abroad aimed to evaluate the effectiveness of choice-making opportunity in increasing student's engagement in activities, and the findings revealed that it did improve their participation (Chickie-Wolfe, 1998; Dibley \& Lim, 1999; Jolivette, 1999; Parsons, Reid, Reynolds \& Bumgarner, 1990). However, merely a single study, which is about the effects of providing choice-making opportunity to students with autism on their behaviors (Ülke Kürkçüoğlu, 2007), is available in the national literature. This limitation proves why more research on this subject is needed in Turkey. It is believed that defining experiences that teachers go through and situations that they encounter during leisure time activities chosen by students with intellectual disability will contribute to the field. As no research about the experiences that teachers undergo during leisure time activities chosen by intellectually 
disabled students is detected, such a study can address the gap spotted.

\section{Purpose}

The overall purpose of this study was to reveal the teachers' experiences, opinions and suggestions regarding leisure time activities chosen by students with intellectual disability. In accordance with this purpose, answers to the questions given below have been sought:

- What did you experience when you allowed your students with intellectual disability to choose among leisure time activities?

- What did you experience while teaching the leisure time activities chosen by your intellectually disabled students?

- What did you experience when your intellectually disabled students were engaged in the activities that they chose on their own in terms of classroom management, students' problem behaviors, students' social skills?

- What did you experience with respect to the intellectually disabled students' duration of engagement in the leisure time activities that the students chose on their own?

- What did you experience with the administration when students with intellectual disability were engaged in the leisure time activities that the students chose on their own?

\section{Method}

\section{Research Model}

This study was designed based on qualitative research pattern. Open ended questions were used to reveal the experiences that the teachers went through while their students with intellectual disability were engaged in leisure time activities which the students had chosen on their own. In accordance with its purpose, this study employed typical case study method, which is one of the qualitative research models used to unveil a typical case or event (Y1ldirım \& Şimşek, 2016).

\section{Participants}

The participants were chosen through criterion sampling, which is one of the purposive sampling techniques. The following criteria were set for sampling by the researchers:

- Being employed in a special education school supported with the project numbered 2017.02.07.1250, where twenty leisure time activities selected after consulting three teachers with at least five years of experience in working with intellectually disabled students were used,

- observing intellectually disabled students' engagement in those activities for at least three weeks,

- having at least three years of experience in working with intellectually disabled students.

25 volunteer teachers who met the criteria took part in the study. Table 1 shows the demographics of the participants. 
Table 1. Demographic Features of the Participants

\begin{tabular}{|c|c|c|c|c|c|c|}
\hline $\begin{array}{l}\text { Code } \\
\text { name }\end{array}$ & Age & Gender & Education & Field of study & Institution & Experience \\
\hline $\mathrm{T} 1$ & 49 & $\mathrm{~F}$ & B.A. & Foreign languages & Vocational school & 25 \\
\hline $\mathrm{T} 2$ & 30 & M & B.A. & Special education & Vocational school & 7 \\
\hline T3 & 35 & M & B.A. & Special education & Vocational school & 13 \\
\hline $\mathrm{T} 4$ & 30 & $\mathrm{~F}$ & B.A. & Special education & Vocational school & 8 \\
\hline T5 & 30 & $\mathrm{~F}$ & B.A. & Special education & Vocational school & 8 \\
\hline T6 & 37 & M & B.A. & Special education & Vocational school & 14 \\
\hline $\mathrm{T} 7$ & 63 & $\mathrm{~F}$ & B.A. & Classroom education & Vocational school & 45 \\
\hline $\mathrm{T} 8$ & 47 & $\mathrm{~F}$ & B.A. & Special education & Vocational school & 20 \\
\hline T9 & 39 & $\mathrm{~F}$ & B.A. & Classroom education & $\begin{array}{l}\text { Special education } \\
\text { middle school }\end{array}$ & 15 \\
\hline $\mathrm{T} 10$ & 37 & $\mathrm{~F}$ & B.A. & Classroom education & $\begin{array}{l}\text { Special education } \\
\text { middle school }\end{array}$ & 6 \\
\hline $\mathrm{T} 11$ & 37 & M & B.A. & Classroom education & Vocational school & 12 \\
\hline $\mathrm{T} 12$ & 30 & $\mathrm{~F}$ & B.A. & Classroom education & $\begin{array}{l}\text { Special education } \\
\text { middle school }\end{array}$ & 8 \\
\hline $\mathrm{T} 13$ & 36 & $\mathrm{~F}$ & B.A. & Special education & Vocational school & 14 \\
\hline $\mathrm{T} 14$ & 36 & $\mathrm{~F}$ & B.A. & $\begin{array}{l}\text { Accommodation } \\
\text { management }\end{array}$ & Vocational school & 2 \\
\hline $\mathrm{T} 15$ & 39 & $\mathrm{~F}$ & B.A. & Classroom education & Vocational school & 8 \\
\hline T16 & 31 & $\mathrm{~F}$ & B.A. & Special education & $\begin{array}{l}\text { Special education } \\
\text { middle school }\end{array}$ & 9 \\
\hline T17 & 30 & M & B.A. & Special education & Vocational school & 7 \\
\hline $\mathrm{T} 18$ & 41 & $\mathrm{~F}$ & B.A. & Special education & Vocational school & 18 \\
\hline T19 & 34 & $\mathrm{~F}$ & B.A. & Special education & Vocational school & 9 \\
\hline $\mathrm{T} 20$ & 36 & $\mathrm{~F}$ & B.A. & Special education & $\begin{array}{l}\text { Special education } \\
\text { middle school }\end{array}$ & 11 \\
\hline $\mathrm{T} 21$ & 35 & $\mathrm{~F}$ & B.A. & Classroom education & $\begin{array}{l}\text { Special education } \\
\text { middle school }\end{array}$ & 10 \\
\hline $\mathrm{T} 22$ & 39 & M & B.A. & Special education & Vocational school & 15 \\
\hline $\mathrm{T} 23$ & 40 & $\mathrm{~F}$ & B.A. & Special education & Vocational school & 17 \\
\hline $\mathrm{T} 24$ & 35 & $\mathrm{~F}$ & B.A. & Classroom education & $\begin{array}{l}\text { Special education } \\
\text { middle school }\end{array}$ & 8 \\
\hline $\mathrm{T} 25$ & 38 & $\mathrm{M}$ & B.A. & Special education & Vocational school & 12 \\
\hline
\end{tabular}

Off all the participants are in the 30-49 age range, 18 were females and 7 were males. 15 of them held a B.A. degree in special education, 10 in classroom education, 1 in foreign languages education and 1 in accommodation management. Their professional experience durations ranged from 4 to 25 years. 18 were working in a vocational school while the others were working in a special education middle school.

\section{Data Collection}

The following questions were asked to the teachers to determine their experiences regarding the leisure time activities selected by their students with intellectual disability:

(1) What did you experience when you gave your students the opportunity to choose a leisure time activity?

(2) What did you experience while teaching your students the leisure time activity that they had chosen?

(3) What did you experience when your intellectually disabled students were engaged in the activities that they chose on their own in terms of classroom management, students' problem behaviors, and students' social skills? 
(4) What were your experiences related to the duration of your students' engagement in the leisure time activity which they had chosen?

(5) What were your experiences with the administration when your students were engaged in the leisure time activity which they had chosen?

The data was collected with data collection forms including open-ended questions. The initial form was prepared after a literature review; then it was finalized by consulting experts in the field of special education. However, using a questionnaire which consisted of open-ended questions came along with both an advantage and disadvantage. The advantage it offered was that the teachers were able to answer the questions without feeling under pressure since there was no face-to-face interaction with the participants. Its disadvantage, on the other hand, was that there was no chance to ask follow-up questions to the participants. A total of 50 pages of data was collected from the teachers in the study.

\section{Data Analysis}

The data collected from the teachers with open-ended questions were analyzed using descriptive analysis method. The processes involved in the analysis are given below.

The teachers' responses were transferred to the computer without making any changes.

In order not to reveal their identities, code names like S1, S2 etc were used.

Responses were categorized under relevant questions.

Each response was read several times.

Codings were made based on the theme of each question.

The frequency of the codes was recorded and some quotes by the participants were included.

\section{Validity and Reliability}

Triangulation of data sources was used for internal validity of the study (Y1ldirım \& Şimşek, 2016). To be able to test the accuracy of the data obtained with the forms, the teachers were asked to keep a diary throughout the research, and 3 diaries taken from the participants who had volunteered to share them with the researchers previously were analyzed. The owners of the diaries which were analyzed were all females in the 5-12 year-experience range. The analysis of the diaries revealed that the teachers had no difficulty in teaching the leisure time activities and those activities' rules to the students with intellectual disability; the students generally seemed to be happy when they were engaged in the activities provided in accordance 
with the project, and they wanted to spend more time doing such activities. Some examples to these statements are below:

T4. Week 1. Day 2 "Initially, it was challenging to teach how to play the game to However, after s/he learned it, s/he was very happy and fond of playing it".

T4. Week 3. Day 4 "The time wasn't enough for the students, and they wanted to keep playing with the toys during the break, too".

T1. Week 3. Day 4" started to cry all of a sudden during the class. S/He said s/he wanted to go home. When I said that we were going to play games, s/he changed her/his mind and got interested in the toys."

For external validity, purposive sampling was used. Within the scope of reliability, verification review was conducted. The data was recorded by another expert in the field, and differing codes were negotiated and finalized through face-to-face interaction.

\section{Findings}

This part includes the findings about what the special education teachers experienced during the leisure time activities chosen by their intellectually disabled students. The answers were given using code names. The questions asked in the research are set as categories and their frequencies are shown in the tables. The findings are presented in the same order as the questions.

\section{The Findings on Teachers' Experiences regarding Giving Intellectually Disabled Students the Opportunity to Choose Among Different Leisure Time Activities}

The answers given to the first question, which was 'What did you experience when you allowed your students with intellectual disability to choose among leisure time activities?' are shown in Table 1.

Table 1. The Findings on the Teachers' Experiences regarding Giving Intellectually Disabled Students the Opportunity to Choose among Different Leisure Time Activities

\begin{tabular}{ll}
\hline Answers & f \\
\hline My students decided on their own. & 22 \\
Because my students couldn't make a choice, I guided them. & 3 \\
\hline
\end{tabular}

Based on Table 1, it can be concluded that the majority of the teachers stated that the students with intellectual disability could choose leisure time activities without any assistance. Along with that, the teachers reshaped the activities in accordance with their students' individual characteristics before they asked the students to make a choice among those options. The original responses given by the special education teachers are below:

T2: "The students were very happy when they saw the toys. When I said they could play with them, they rejoiced and chose the toy they wanted"

T5: "Because they did not have much difficulty in making their own decisions, they easily made a choice after a brief explanation about all the games and I did not have much difficulty" 
T7: "They made their own choices with great enthusiasm and joy."

T9: "I ensured that the students selected appropriate activities for their special conditions. For example, I made sure that one of our students, who could not use hand muscles comfortably, chose another game rather than the Super Doctor game."

T23: "I directed them. Those children are not capable of making choices."

T24: "I lined up the games. Then, I asked the students to make their choices. They played with their choice of toys"

\section{The Findings on Teachers' Experiences regarding Teaching the Leisure time Activities Chosen by Students with Intellectual Disability}

The answers given to the question, 'What did you experience while teaching the leisure time activities chosen by your intellectually disabled students?', are given in Table 2.

Table 2. The Findings on Teachers' Experiences regarding Teaching the Leisure time Activities Chosen by Students with Intellectual Disability

\begin{tabular}{ll}
\hline Answers & f \\
\hline I had no trouble. & 18 \\
I explained them through exemplification. & 7 \\
I taught them by playing with them. & 2 \\
\hline
\end{tabular}

Table 2 shows that the majority of the teachers stated they did not have trouble teaching the leisure time activities and their rules to the students with intellectual disability; while some games had to be exemplified as they were relatively hard to learn for the students. The teachers also played some games with their students to teach the games and their rules, and they taught some games through repetition. The original responses given by the special education teachers are as follows:

T6. 'They mostly learned the game on their own'

T7. 'While playing games including a lot of parts, the students had difficulty, but I overcame this problem by teaching them the tips of the games'

T2. "They were so interested in the games that they listened to me very carefully, so I had no problem teaching the games"

T3. "My student with autism initially had trouble with regard to the order and direction of colors, but once s/he understood it, s/he did it without any trouble. The second student also had trouble with the direction, but I solved this problem through repetition"

\section{The Findings on the Teachers' Experiences regarding Classroom Management, Students' Problem Behaviors, and Students' Social Skills during the Leisure time Activities Chosen by the Students}

The answers given to the question, 'What did you experience when your intellectually disabled students were engaged in the activities that they chose on their own in terms of 
classroom management, students' problem behaviors, students' social skills?", are shown in Table 3.

Table 3. The Findings on the Teachers' Experiences regarding Classroom Management, Students' Problem Behaviors, and Students' Social Skills during the Leisure time Activities Chosen by the Students

\begin{tabular}{lc}
\hline Answers & f \\
\hline About classroom management, & 24 \\
I had no trouble. & 1 \\
I had trouble. & $\mathbf{f}$ \\
\hline About problem behaviors, & 18 \\
I had problems. & 5 \\
I had fewer problems. & $\mathbf{f}$ \\
\hline About students' social skills, & 16 \\
\hline There was improvement in their skills & 4 \\
There was improvement in their communication skills & 3 \\
There was improvement in their cooperation skills & 3 \\
There was improvement in their setting up games and playing according to its rules & 2 \\
There was improvement in their assistance skills & 2 \\
There was improvement in their sharing skills & 2 \\
There was improvement in their accepting defeat with maturity & 1 \\
There was improvement in their asking for permission & 1 \\
There was improvement in their taking responsibility & \\
\hline
\end{tabular}

Table 3 shows that most of the teachers stated that they had no trouble with classroom management during the leisure time activities; the students didn't exhibit problem behaviors, and there were fewer problem behaviors. Also, they mentioned that those activities resulted in improvement in students' social skills, cooperation, communication, assistance, responsibility acceptance, maturity upon defeat, sharing and turn-taking skills. What is more, they shared the students were able to set up games and played them following the rules better, and their frequency of getting permission enhanced. The original responses given by the special education teachers are below.

T12 "They usually played the games in groups. They took turns during the games and played them according to the rules. When they did not, we warned them verbally"

T15. "I had no bad experience. On the contrary, the children behaved better"

T9 "Their constantly swapping toys because of the surplus caused me a bit of trouble"

T15. "I observed a decrease in negative behaviors and more active participation in the class"

T17. "I observed a decrease in problem behaviors. Their problem behaviors gradually reduced as they were interested in the games and were adopt to them"

T8. "The games extended their attention spans, and the games were effective in increasing their self-esteem"

T11. "They had an efficient and quality time. In addition, their skills related to taking and waiting for turns as well as their communication and interaction developed during the group 
games. I believe such games help students to develop strategy, increase pace, think practically and acquire psychomotor skills."

T13. "Students should be allowed to spend time with educational games in order to diminish and eliminate inappropriate behaviors."

T14. "Their language skills improved. They also had a good time with their friends. They became more harmonious as part of a group. They became more eager to come to school, too."

T23. "Thanks to the group games, they learned to play and act together by sharing toys during the game."

T8. "They played the leisure time games in harmony. They had the excitement and joy of learning. The children felt good and learned through fun. There was no difficulty in management. They were managed with ease."

T10. "Educational games are not only fun but also beneficial for children since they contribute to their cognitive development. So, more time should be allocated to educational games at schools"

T13. "Leisure time activities should be definitely used because they are very important for our students"

\section{The Findings on the Teachers' Experiences regarding the Duration of Intellectually Disabled Students' Engagement in the Leisure time Activities}

The answers given to the question, 'What did you experience related to the intellectually disabled students' duration of engagement in the leisure time activities that the students chose on their own?', are shown in Table 4.

Table 4. The Findings on the Teachers' Experiences regarding the Duration of Intellectually Disabled Students' Engagement in the Leisure time Activities

\begin{tabular}{lc}
\hline Answers & f \\
\hline Class hour wasn't enough. & 15 \\
Class hour was enough. & 7 \\
\hline
\end{tabular}

Table 4 shows that the teachers used the class hour for the leisure time activities, but it was not enough. The original responses given by the special education teachers are below:

T3. "One class hour was allocated, and the students participated without getting bored as time passed."

T17. "Since I observed that one class hour was not sufficient and the children wanted to play more, I sometimes used my initiative and extended the time. I saw them playing even during breaks"

T24 "They wanted to play longer. In every lesson, they suggested playing game." 


\section{The Findings on the Teachers' Experiences with the School Administration regarding the Leisure time Activities}

Table 5 includes the answers given by special education teachers to the question What did you experience with the administration when students with intellectual disability were engaged in the leisure time activities that the students chose on their own?'

Table 5. The Findings on the Teachers' Experiences with the School Administration regarding the Leisure time Activities

\begin{tabular}{lc}
\hline Answers & f \\
\hline I didn't have any problems. & 19 \\
\hline
\end{tabular}

When Table 5 is examined, it can be seen that the teachers had no trouble with the school administration as to the leisure time activities chosen by the students with intellectual disability. The teachers' original responses are quoted below:

\section{T13. "We did not have any problem with the administration as it did not affect our classes"}

T22. "Our headmistress made positive contributions to the project by supporting it and us"

T23. "I didn't have any trouble. The school administration was very happy about those games."

T24. "I have the most problematic student at school. S/he used to leave the classroom and wander around the garden in every lesson. When the principal and his assistants couldn't see the student in the garden, they asked me 'what I had done to him/her'. The kid was so hooked that s/he didn't want to go out even during the breaks."

T25. "There were no problems. The vice principal even expressed his happiness since the children were very quiet."

To conclude, the teachers stated that the students with intellectual disability could choose the leisure time activities on their own; the teachers reshaped the activities in accordance with the students' individual characteristics, and they asked the students to make a choice among those activities. The teachers also articulated that they did not have difficulty teaching the leisure time activities and their rules to the students with intellectual disability; some games had to be exemplified as they were difficult to learn for the students, though. The teachers taught some games by playing them with the children, and some others through repetition. In addition, they mentioned that they had no problem in terms of classroom management during the leisure time activities; the students did not exhibit a lot of problem behaviors, and there was even a decrease in such behaviors. Apart from these, they mentioned that those activities resulted in improved social skills, cooperation, communication, assistance, responsibility, maturity upon defeat, sharing, interaction and turn-taking skills. Also, they mentioned that the students were better at setting up games and playing them following the game rules. They encouraged the students to ask for permission more often, as well. As for the activity time, the participants stated that they used the class hour, which they found insufficient. Lastly, the special education teachers underlined that they did not have any problems with the administration in relation to the leisure time activities chosen by the students with intellectual disability. 


\section{Discussion}

Based on the findings of this study, which aimed to reveal the experiences of special education teachers regarding leisure time activities chosen by students with intellectual disability, it can be said that the students were able to choose the activities on their own and the teachers did not encounter any serious problems in that process. It is believed that intellectually disabled students should engage in activities that they choose, and they should spend time doing such activities, through this way, they can efficiently use their leisure time. In her study, Gülay Ogelman (2014) observed leisure time activities in preschool classes in Denizli province from various angles and she revealed that the students were able to decide on the activities to be done. In this respect, the findings of the research done by Gülay Ogelman (2014) are parallel with the findings of this research.

Choice making is giving a person the opportunity to make a decision and choose one among various available options depending on one's needs, wishes and values; thus, it improves his/her life quality (Martin, Yu, Martin \& Fazzio, 2006). In this manner it can be claimed that when people deal with something (activity, friend, food, beverage, equipment etc.) that they have chosen in accordance with their desires, this will provide them with a better experience, and their life quality will improve. Likewise, the students mostly had a good time while doing the activities that they chose with their friends in this study.

The field literature emphasizes the significance of teaching the choice making skills to intellectually disabled individuals, creating suitable environments that will enable them to demonstrate their choices and practicing those skills. According to Dunlap and Liso (2004), practices which involve choice-making include giving pupils the opportunity to make their own decision and indicate their preferences before providing them with an activity or object. Giving this opportunity to intellectually disabled individuals aims to help them develop their communication skills (Carter, 2001). This is because giving such an opportunity during a leisure time activity can strengthen the communication and interaction between the person who gives the opportunity and the other person who is given it, as well as increasing interaction with peers. Similarly, one of the findings of the study indicated that allowing the students to choose leisure time activities improved their communication and interaction with both their teachers and their peers. Thereupon, this finding appears to be consistent with other relevant findings in the literature.

The teachers stated that their students were happy to spend time doing the leisure time activities that they chose on their own. The teachers also mentioned that they did not have difficulty in teaching those games to the students. Another purpose of giving the choice making opportunity to individuals with disability is to ensure their satisfaction (Green at al., 1988) so that they feel happy during a leisure time activity. It can be concluded that this aim has been achieved in this study.

Another purpose of providing an intellectually disabled individual with choice making opportunity is to increase his/her motivation (Katz \& Assor, 2007). Therefore, it is not wrong to claim that choosing an activity will increase an individual's interest and motivation and, students' choosing an activity on their own can increase their motivation as well. Another finding of the study is that giving this opportunity to the students resulted in a decrease in inappropriate student behaviors. The finding is supported by the studies available in the relevant literature (Romaniuk \& Miltenberger, 2001; Shogren et al., 2004). Considering the findings of this study, it can be said that choice making opportunity has served its purposes in that sense. 
In their study on the effects of leisure time activities on the youth's personality, social and educational development, Büküşoğlu and Bayturan (2005) found out that those activities had a positive impact on the participants' social skills. It was observed that there was an improvement in students' social skills such as self-recognition, self-expression and taking responsibility. Similar results can be found among the findings of this research. The teachers mentioned that those activities resulted in improved social skills, cooperation, communication, assistance, responsibility, maturity upon defeat, sharing and turn-taking skills. Also, they stated the students could set up games and played them following the rules better. In addition, there was an improvement in the frequency of their getting permission. To that end, the findings of this study seem consistent with those of Büküşoğlu and Bayturan (2005).

Another finding of the study is that one class hour was not enough for the leisure time activities. Students took delight of the activities without even noticing the time as they were doing the activities of their choice with joy. The students wanted to play more in the next class hour. Based on these findings, it can be arguably be uttered that they have a good time when they are engaged in leisure time activities of their choice. Another study done by Gülay Ogelman (2014) demonstrated that the majority of the preschool teachers allocated more than one class hour to such activities, and still this was not enough. In light of this, the findings of this study support what is shred in the literature (Gülay Ogelman, 2014).

Finally, the teachers stated that they did not have any issues with the school administration related to the leisure time activities; on the contrary, the administration was apparently happy with the process as it prevented inappropriate student behaviors in the classroom and school. Student involvement in leisure time activities which they choose is likely to reduce or prevent problem behaviors both in classroom and school settings. Thusly it can be concluded that such activities may provide them with psychological, physical and social benefits as well as healthbenefits. From this point of view, the findings of this study are parallel with the ones revealed by Güçlü (2013), who theoretically studied the role and importance of leisure time activities for young people. Güçlü (2013) found out that those activities had a prominent place in young people's lives and they impact them positively in many aspects (physical, psychological etc.).

One of the issues that should be discussed in line with this research is its limitations, though. The study is limited to the students and teachers who were involved in this study as well as the leisure time activities chosen by the teachers and students only.

\section{Conclusion and Recommendations}

To conclude, the special education teachers underpinned that their students with intellectual disability could choose leisure time activities by themselves; the teachers reshaped the activities in accordance with their students' individual characteristics, and they asked the students to choose among those options. In addition, the participants mentioned that they experienced no problems in terms of classroom management during the leisure time activities; the students did not exhibit problem behaviors, and the teachers observed a decline in such behaviors. Moreover, they asserted that those activities resulted in improved social skills, cooperation, communication, assistance, responsibility, maturity upon defeat, sharing, interaction and turn-taking skills among the students. Also, they mentioned that the students were better at setting up games and playing them following the rules. It was also stated that the games encouraged the students to ask for permission more often. However, considering the qualitative aspect and the limitations of this study, the following can be suggested: 
- Individuals with intellectual disability were involved in this study. Further research can be conducted with individuals with other types of disabilities.

- 25 volunteer teachers participated in the study. Other studies can be conducted with more teachers.

- Alongside qualitative methods, quantitative methods can be employed in a similar study.

- Further studies including different leisure time activities can be carried out.

- Students can be taught the choice-making skills.

- Students can be given the opportunity to make choices among various options.

- The number of classes in which leisure time activities are executed can be increased.

\section{Acknowledgements or Notes}

This study was supported by the Bolu Abant İzzet Baysal University Scientific Research Projects Coordination Unit and the summary was presented in International Necatibey Education and Social Sciences Research Congress (26-28 October 2018, Balıkesir, Turkey).

\section{References}

Barry, L., \& Burlew, S. (2004). Using social stories to teach choice and play skills to children with autism. Focus on Autism and Other Developmental Disabilities, 19(1), 45-51.

Bult, M. K., Verschuren, O., Jongmans, M. J., Lindeman, E., \& Ketelaar, M. (2011). What influences participation in leisure activities of children and youth with physical disabilities? A systematic review. Research in developmental disabilities, 32(5), 15211529.

Büküşoğlu, N., \& Bayturan, A.F. (2005). Serbest zaman etkinliklerinin gençlerin psiko-sosyal durumlarına ilişkin algısı üzerindeki rolü [The role of leisure time activities on the concept related to the psycho - social development of the youth]. Ege Tip Dergisi [Ege medicine journal], 44(3), 173-177.

Carter, C. M. (2001). Using choice with game play to increase language skills and interactive behaviors in children with autism. Journal of Positive Behavior Interventions, 3, 131151.

Clark, C. D. (2006). Teahing choice making to children with visual impairments and multiple disabilities in preschool and kindergarten classrooms. (Unpublished Doctorate Dissertation), The University of Utah, Salt Lake City, Utah.

Cote Sparks, S. \& Cote, D.L. (2012). Teaching Choice Making to Elementary Students With Mild to Moderate Disabilities. Intervention in School and Clinic 47(5), 290-296.

Cole, C. L., \& Levinson, T. R. (2002). Effects of within-activity choices on the challenging behavior of children with severe developmental disabilities. Journal of Positive Behavior Interventions, 4(52), 29-37.

Chickie-Wolfe, L. A. (1998). Effects of choice making on the adaptive behaviors of adolescents with emotional disturbance. (Unpublished Doctorate Dissertation), Vanderbilt Universitesi, Nashville, Tennessee, ABD.

Çay, E. (2017). Zihinsel yetersizliği olan bireylere serbest zaman becerilerinin küçük grupla ögretiminde video ipucunun etkililiği [The effectiveness of video prompting in small groups teaching of leisure time skills to individuals with intellectual disabilities]. (Unpublished Master Dissertation), Abant İzzet Baysal University, Bolu.

Duke, J. M. (2008). Teaching students with multiple disabilities to respond to choises using photographes. (Unpublished Doctorate Dissertation), The Johns Hopkins University, Baltimore, Maryland. 
Dunlap, G., DePerczel, M., Clarke, S., Wilson, D., Wright, S., White, R., vd. (1994). Choice making to promote adaptive for students with emotional and behavioral challenges. Journal of Applied Behavior Analysis, 27, 505-518.

Dunlap, G., \& Liso, D. (2004). Using choice and preference to promote improved behavior. What Works Brief Series, Erişim 30/08/2004, http://csefel.uiuc.edu.

Dutt, A. S. K. (2010). The effects of skill training on preference for individuals with severe to profound multiple disabilities. The Doctor of thesses in the Graduate College of The University of Iowa.

Dibley, S., \& Lim, L. (1999). Providing choice making opportunities within and between daily school routines. Journal of Behavioral Education, 9(2), 117-132.

Eldeniz-Çetin, M. (2013). Ăğ ve çoklu yetersizliği olan bireylerin tercihlerinin değerlendirilmesi ve seçim yapma becerisinin ögretimi [Preference assessment in individuals with profound and multiple disabilities and teaching choice-making]. (Unpublished Doctorate Dissertation), Gazi University, Institute of Education Sciences, Ankara.

Farry, W. (2008). The effects of video modeling on leisure time activities for learners with severe special needs. (Unpublished Doctorate Dissertation), Arizona State University, USA.

Foster-Johnson L, Ferro J, \& Dunlap G. (1994). Preferred curricular activities and reduced problem behaviors in students with intellectual disabilities. Journal of Applied Behavior Analysis. 27(3), 493-504.

Göçer, A. (2004). Türkçe öğretimine bir uygulama sahası olarak belirli günler ve haftaların kutlama etkinlikleri [Celebration activities of certain days and weeks as a field of practice for Turkish language teaching]. Milli Eğitim Dergisi [Journal of National Education], 32(162), 1302-5600.

Gülay Ogelman, (2014). Okul öncesi eğitim kurumlarında serbest zaman etkinliklerinin gözlemlenmesi [Observation of leisure time activities at preschool educational institutions], Mustafa Kemal Üniversitesi Sosyal Bilimler Enstitüsü Dergisi [Mustafa Kemal University Journal of Graduate School of Social Sciences], 11(26), 125-138.

Güçlü, M. (2013). Gençlik döneminde boş zaman faaliyetlerinin yeri ve önemi [The significance and importance of leisure time activities in youth period], Gençlik Araştırmaları Dergisi [Journal of Youth Research], 1(1), 2147-8473.

Green, C. W., Reid, D. H., White, L. K., Halford, R. C., Brittain,D. P., \& Gardner, S. M. (1988). Identifying reinforcers for persons with profound handicaps: Staff opinion versus systematic assessment of preferences. Journal of Applied Behavior Analysis, 21, 31-43.

Hanley, G P., Cammilleri, A. P., Tiger, J. H., \& Ingvarsson, E. T. (2007). Towards a mothod for describng preschoolers' activity preferences. Journal of Applied Behavior Analysis, 40, 603-618.

Harding, J. W., Wacker, D. P., Berg, W. K., Barreto, A., \& Rankin, B. (2002). Assessment and treatment of severe behavior problems using choice making procedures. Education and Treatment of Children, 25(1), 26-46.

Hoch, C. (2006). Emotions and planning. Planning Theory \& Practice, 7, 367-382.

Jolivette, K. (1999). Effects of choice making opportunities on the behaviors of students with emotional and behavioral disorders. (Unpublished Doctorate Dissertation), Vanderbilt Universitesi, Nashville, Tennessee.

Jolivette, K.,Stichter, J. P., Sibilsky, S., Scott, T. M., \& Ridgley, R. (2002). Naturally occurring opportunities for preschool children with or without disabilities to make choices. Education and Treatment of Children. 25, 395-414. 
Kearney, C. A., \& McKnight, T. J. (1997). Preference, choice, and persons with disabilities: A synopsis of assessments, interventions, and future directions. Clinical Psychology Review, 17, 217-238.

Law, M., King, G., King, S., Kertoy, M., Hurley, P., Rosenbaum, P., \& Hanna, S. (2006). Patterns of participation in recreational and leisure activities among children with complex physical disabilities. Developmental Medicine and Child Neurology, 48(05), 337-342.

Martin, T. L., Yu, C. T., Martin, G. L., \& Fazzio, D. (2006). On choice, preference and preference for choice. The Behavior Analyst Today, 7(2), 234-241. Doi: $10.1037 / \mathrm{h} 0100083$

Majnemer, A., Shevell, M., Law, M., Birnbaum, R., Chilingaryan, G., Rosenbaum, P., \& Poulin, C. (2008). Participation and enjoyment of leisure activities in school-aged children with cerebral palsy. Developmental Medicine and Child Neurology, 50(10), 751-758.

Murphy, E. S., McSweeney, F. K., Smith, R. G., \& McComas, J. J. (2003). Dynamic changes in reinforcer effectiveness: Theoretical, methodological, and practical implications for applied research. Journal of Applied Behavior Analysis, 36, 421-438.

Megep, (2007). Çocuk gelişimi ve eğitimi. Serbest zaman etkinlikleri [Child development and education. Leisure activities]. Ankara.

Mccormick, K. M., Julivette, K., \& Ridgley, R. (2003). Choice making: As an intervention strategy for young children. Young Exceptional Children, 6(2), 3-10. https://doi.org/10.1177/109625060300600202

Newman, B., Needelman, M., Reinecke, D. R. \& Robek, A. (2002). The effect of providing choices on skill acqusition and competing behavior of children with autism during discrete trial instruction. Behavioral Interventions, 17, 31-41.

Parsons, M. B.,Re1d, D. H., Reynolds, J., \& Bumgarner, M. (1990). Effects of chosen versus assigned jobs on the work performance of persons with severe handicaps. Journal of Applied Behavior Analysis, 23(2), 253-258. doi:10.1901/jaba.1990.23-253

Peterson, S. M. P., Caniglia, C., \& Royster, A. J. (2001). Application of choice-making intervention for a student with multiply maintained problem behavior. Focus on Autism and Other Developmental Disabilities, 16(4), 240246.

Peck, S. M., Wacker, D. P., Berg, W. K., Cooper, L. J., Brown, K. A., Richman, D., McComas, J. J., Frischmeyer, P. \& Millard, T. (1996). Choice-making treatment of young children's severe behavior problems. Journal of Applied Behavior Analysis, 29(3), 263290.

Romaniuk, C.,Miltenberger, R., Conyers, C., Jenner, N., Jurgens, M., \& Ringenberg, C. (2002). The influence of activity choice on problem behaviors maintained by escape versus attention. Journal of Applied Behavior Analysis, 35(4), 349-362.

Romaniuk, C., \& Miltenberger, R. G. (2001). The influence of preference and choice of activity on problem behavior. Journal of Positive Behavior Interventions, 3(3), 152-159. https://doi.org/10.1177/109830070100300303

Preskitt, J. K., Goldfarb, S. S., Mulvihill, B. A., Colburn, S., \& Davis, M. M. (2013). Future plans and social/recreational activities of youth with special health care needs: The implications of parental help in completing surveys. Disability and health journal, 6(4), 343-351.

Sarikaya, İ., (2013). Serbest zaman etkinlikleri dersinin ögretmen görüşlerine göre incelenmesi [Examination of leisure time course according to teachers' opinions.]. (Unpublished Master's Dissertation), Atatürk University, Erzurum. 
Shogren, K. A., Faggelle-Luby, M. N., Bae, S. J., \& Wehmeyer, M. L. (2004). The effect of choice-making as an intervention for problem behavior. Journal of Positive Behavior Interventions, 6(4), 228-237.

Shevin, M., \& Klein, N. K. (2004). The importance of choice-making skills for students with severe disabilities. Research \& Practice for Persons with Severe Disabilities, 29, 161168.

Spevack, S., Martin, T. L., Heibert, R., Yu, C. T., \& Martin, G. L. (2004). Effects of choice of work tasks on on-task, aberrant, happiness and unhappiness behaviors of persons with developmental disabilities. Journal on Developmental Disabilities, 11(2), 79-97.

Sucuoğlu, B. (2009). Zihin engelliler ve eğitimleri[Intellectual disability and their education]. Ankara: Kök Yayıncılık, Şubat.

Stafford, A. M. (2005). Choice making: A strategy for students with severe disabilities. Teaching Exceptional Children, 37(6), 12-17.

Ülke Kürkçüoğlu, B. (2007). Otistik özellik gösteren çocuklara sunulan seçim firsatları ve etkileri [Providing choice-making opportunities to and its effects on children with autism]. Ankara Üniversitesi Ĕgitim Bilimleri Fakültesi Özel Eğitim Dergisi [Ankara University Faculty of Educational Sciences Journal of Special Education], 8 (2) 67-83.

Ülke-Kürkçüoğlu, B. (2007). Otistik özellik gösteren çocuklara bire-bir ögretimde etkinlikler içi ve arası seçim firsatları sunmanın etkilerinin karşılaştırılması [Comparison of the effects of presenting in-between and between-activity opportunities for autistic children in one-to-one instruction]. (Unpublished Doctorate Dissertation), Anadolu University, Eskişehir, Türkiye.

Watanabe, M., \& Sturmey, P. (2003). The effect of choice-making opportunities during activity schedules on task engagements of adults with autism. Journal of Autism and Developmental Disorders, 33, 535- 538.

Wehmeyer, M. L. (2003). Self-determination, vocational rehabilitation and workplace supports. Journal of Vocational Rehabilitation, 19, 67-69.

Wood, W. M., Karvonen, M., Test, D. W., Browder, D. \& Algozzine, B. (2004). Promoting student self determination skills in IEP planning. Teaching Exceptional Children, 36(3), 8-16.

Vaughn, B. J., \& Horner, R. H. (1997). Identifying instructional tasks that occasion problem behaviors and assessing the effects of student versus teacher choice among these tasks. Journal of Applied Behavior Analysis, 30(2), 299-312.

Yıldırım, A., \& Şimşek, H. (2016). Sosyal bilimlerde nitel araştırma yöntemleri [Qualitative research methods in the social sciences]. Ankara: Seçkin Yayınc1lık. 